\title{
66. NATURE, ORIGIN, AND PETROLEUM SOURCE POTENTIAL OF ORGANIC MATTER FROM DEEP SEA DRILLING PROJECT SITES 434, 435, 438, AND 440 IN THE JAPAN TRENCH
}

\author{
Deborah Gilbert, Colin P. Summerhayes, and David L. Johnson, \\ Exxon Production Research Company, Houston, Texas
}

\section{INTRODUCTION}

As part of a continuing program of organic-geochemistry studies of sediments recovered by the Deep Sea Drilling Project, we have analyzed the types, amounts, and thermal-alteration indices of organic matter in samples collected from the landward wall of the Japan Trench on Legs 56 and 57 (Table 1). The samples were canned aboard ship, enabling us to measure also their gas contents (Table 1). In addition, we analyzed the heavy $\mathrm{C}_{15}+$ hydrocarbons, NSO compounds, and asphaltenes extracted from selected samples (Table 2).

Our samples form a transect down the trench wall, from Holes 438 and 438A (water depth $1558 \mathrm{~m}$ ), through Holes 435 and 435A (water depth $3401 \mathrm{~m}$ ), and 440 (water depth $4507 \mathrm{~m}$ ), to Holes 434 and 434B (water depth $5986 \mathrm{~m}$ ). The trench wall is the continental slope of Japan. Its sediments are Cenozoic hemipelagic diatomaceous muds that were deposited where they are found or have slumped from farther up the slope. Their terrigenous components probably were deposited from near-bottom nepheloid layers transported by bottom currents or in low density flows (Arthur et al., 1978). Our objective was to find out what types of organic matter exist in the sediment and to estimate their potential for generation of hydrocarbons.

\section{RESULTS}

Although the sediments are rich in the skeletal remains of marine plants (diatoms), most of the non-skeletal organic matter is terrestrial, consisting of the remains of the higher land plants (Table 1). Woody material is predominant at most sites; coaly and herbaceous materials (including pollen and spores) are the most important secondary components. Together, these three terrestrial components make up about 75 per cent of the insoluble organic matter in our samples. Some of the kerogen samples contain as much as 30 per cent of pollen and spores. The pollen grains are mostly from mangrove, alder, and birch. Most of the kerogen appears fresh, but some has been reworked from older sediments.

Algal or amorphous organic matter makes up the rest of the kerogen assemblage in these samples (Table 1). The algal material is marine. The amorphous material is, by definition, unstructured, and may be marine or terrestrial. Its abundance is not covariant with that of any other type of organic matter.

Gas chromatograms of the $\mathrm{C}_{15}+$ saturated hydrocarbons extracted from selected samples confirm that the organic fraction of these sediments is largely terrestrial (Figure 1). For instance, most of the $\mathrm{C}_{15}+$ saturates are normal paraffins with carbon numbers of 22 or more, and with a strong preference for odd-numbered chains. From the chromatograms, we estimate that about 70 per cent of the extract comes from the remains of higher land plants.

The sediments do not contain much organic matter (Table 1). At Sites 434, 435, and 438, the average totalorganic-carbon content is only 0.72 per cent. It is a little higher at Site $440(0.92 \%)$. Moderate to low levels of total organic carbon like these are typical of continental slopes where the water column is well oxygenated.

From kerogen color, we infer that all the samples are thermally immature; none have been yet altered to the point that they will yield liquid hydrocarbons. Thermalalteration indexes are low ( 2 or less), and carbon preference indexes are high ( 2 or more). Because the sediments are immature, much of the extractable bitumen consists of NSO compounds and asphaltenes, rather than hydrocarbons (Table 2).

All the samples contained some gas, mostly methane (Table 1), with traces of ethane, propane, and butane. Methane is about as abundant in these sediments as it is in other Tertiary and Quaternary sediments cored on the continental slope off Oregon (Sites 174, 176), in the Aleutian Trench (Sites 180, 186), and in the Bering Sea (Sites 185, 189, 191) (McIver, 1973a, 1973b).

\section{INTERPRETATION}

The environment of deposition on the landward wall of the Japan Trench is conducive to the accumulation and preservation of low to moderate amounts of organic matter. Total organic carbon is low because of deposition far from shore, beneath a long, oxidizing water column. Although highly productive surface waters supply the seabed with large amounts of diatom skeletons, there is no comparable build-up of non-skeletal marine organic matter, most of which must be oxidized and dissolved in the upper part of the water column (as off northwest Africa; Milliman, 1977). We assume that terrestrial organic matter, along with mineral grains, is supplied to the seabed from near-bottom nepheloid layers that move down or along the slope. The ultimate source of these materials is Japan. From the abundance of pollen from mangroves, alder, and birch, we deduce that little of the organic matter is transported by wind, although a small fraction may be blown offshore by the prevailing westerlies. Our samples do not show any significant geographic patterns in the distribution of 
TABLE 1

Organic Geochemistry of Gassy Mud Samples from the Landward Wall of the Japan Trench

\begin{tabular}{|c|c|c|c|c|c|c|c|c|c|c|c|c|}
\hline \multirow[b]{2}{*}{$\begin{array}{l}\text { EPR } \\
\text { No. }\end{array}$} & \multirow[b]{2}{*}{$\begin{array}{l}\text { Sample } \\
\text { (interval in } \mathrm{cm} \text { ) }\end{array}$} & \multirow[b]{2}{*}{$\begin{array}{l}\text { Organic } \\
\text { Carbon } \\
\text { (wt. \%) }\end{array}$} & \multirow[b]{2}{*}{ Algal } & \multirow[b]{2}{*}{ Amorphous } & \multirow[b]{2}{*}{$\begin{array}{l}\text { Kerogen Type } \\
\text { relative units) }\end{array}$} & \multirow[b]{2}{*}{ Woody } & \multirow[b]{2}{*}{ Coaly } & \multirow[b]{2}{*}{$\begin{array}{l}\text { Thermal- } \\
\text { Alteration } \\
\text { Index }\end{array}$} & \multirow[b]{2}{*}{$\begin{array}{l}\text { Reworked } \\
\text { Kerogen } \\
\text { Included }\end{array}$} & \multicolumn{3}{|c|}{ Cuttings Gas $\left(\mathrm{C}_{1}-\mathrm{C}_{4}\right)$} \\
\hline & & & & & & & & & & $\begin{array}{c}\mathrm{HC} \text { gas } \\
\text { (vol.ppm) }\end{array}$ & $\begin{array}{c}\mathrm{CH}_{4} \\
\text { in } \mathrm{HC}_{\text {gas }}\end{array}$ & $\begin{array}{c}\mathrm{C}_{2} \mathrm{H}_{6} \\
\text { in wet gas } \\
(\%)\end{array}$ \\
\hline 68950 & 434-19-2, Top Ext. & 0.68 & 2 & 1 & 2 & 3 & 2 & 2 & + & 18400 & 99.93 & 93 \\
\hline $68951 \mathrm{~A}$ & $434 \mathrm{~B}-8-1,132-140$ & 0.88 & 2 & $i$ & 2 & 2 & 3 & 2 & + & 10494 & 99.90 & $85^{\mathrm{a}}$ \\
\hline $68951 \mathrm{~B}$ & $8-2,142-150$ & 0.90 & 2 & $i$ & 2 & 3 & 2 & 2 & & 10609 & 99.96 & $74^{a}$ \\
\hline $68952 \mathrm{~A}$ & $15-1,142-150$ & 0.72 & 2 & $i$ & 2 & 2 & 3 & 2 & & 7431 & 99.92 & $60^{\mathrm{a}}$ \\
\hline $68952 B$ & $16-1,142-150$ & 0.72 & 3 & 1 & 1 & 2 & 3 & 2 & & 5424 & 99.82 & $86^{a}$ \\
\hline \multirow[t]{2}{*}{68953} & $24-1,141-150$ & 0.56 & 3 & 2 & 1 & 2 & 2 & 2 & + & 4997 & 99.91 & 83 \\
\hline & Mean & 0.74 & 2.3 & 1.17 & 1.66 & 2.33 & 2.67 & & & & & \\
\hline 68954 & $435-5-4,145-150$ & 0.56 & 2 & - & 3 & 4 & 1 & 2 & + & 1844 & 99.98 & 58 \\
\hline $68955 \mathrm{~A}$ & $435 \mathrm{~A}-4-1,145-150$ & 1.02 & 2 & 1 & 2 & 2 & 3 & $1+$ & + & 9324 & 99.98 & 89 \\
\hline $68955 \mathrm{~B}$ & $6-2,143-150$ & 0.68 & 2 & 1 & 2 & 2 & 3 & 2- & + & 5761 & 99.98 & 91 \\
\hline \multirow[t]{2}{*}{68956} & $11-2,0-5$ & 0.64 & 2 & i & 2 & 3 & 2 & $2-$ & + & 4830 & 99.96 & 89 \\
\hline & Mean & 0.73 & 2 & 0.8 & 2.25 & 2.75 & 2.25 & & & & & \\
\hline $68941 \mathrm{~A}$ & 438-5-5, Bottom Ext. & 0.32 & 1 & - & 3 & 4 & 2 & 2 & + & 7429 & 99.9 & 76 \\
\hline $68941 \mathrm{~B}$ & 7-4, Top Ext. & 0.90 & - & 2 & 2 & 3 & 3 & $2-$ & + & 81 & 99.1 & 31 \\
\hline $68942 \mathrm{~A}$ & 7-6, Extruded & 0.92 & - & 1 & 2 & 4 & 3 & $2-$ & + & 143 & 98.9 & 58 \\
\hline $68942 \mathrm{~B}$ & 8-4, Bottom Ext. & 0.54 & 1 & 2 & 2 & 3 & 2 & 2- & + & 2946 & 99.94 & 52 \\
\hline $68943 \mathrm{~A}$ & 8-7, Extruded & 0.64 & 1 & 2 & 2 & 2 & 3 & 2- & + & 19761 & 99.94 & 62 \\
\hline $68943 B$ & 9-1, Extruded & 0.72 & 1 & 2 & 2 & 2 & 3 & 2 & + & 264 & 99.77 & 30 \\
\hline $68944 \mathrm{~A}$ & 9-2, Extruded & 0.68 & $i$ & 1 & 2 & 4 & 2 & 2 & + & 5575 & 99.91 & 62 \\
\hline $68944 B$ & 10-5, Extruded & 0.74 & 2 & - & 2 & 4 & 2 & 2 & + & 47 & 99.1 & 55 \\
\hline $68945 \mathrm{~A}$ & 11-2, Top Ext. & 0.56 & - & 2 & 2 & 4 & 2 & 2 & + & 437 & 99.7 & 16 \\
\hline $68945 B$ & 11-3, Top Ext. & 0.58 & 1 & 2 & $\tilde{1}$ & 4 & 2 & 2 & + & 9244 & 99.96 & 91 \\
\hline $68946 \mathrm{~A}$ & 438A-5-4, Bottom Ext. & 0.44 & 2 & 2 & 2 & 2 & 2 & 2 & & 48 & 89.7 & 34 \\
\hline $68946 \mathrm{~B}$ & 10-2, Top Ext. & 1.14 & 4 & 1 & $i$ & 2 & 2 & $2-$ & & 131 & 98.1 & 45 \\
\hline $68947 \mathrm{~A}$ & 16-5, Top Ext. & 0.90 & 1 & 2 & 2 & 2 & 3 & 2- & + & 113 & 99.0 & 56 \\
\hline \multirow[t]{2}{*}{$68947 \mathrm{~B}$} & 20-1, Bottom Ext. & 0.92 & $i$ & $i$ & 3 & 3 & 2 & 2- & + & 152 & 98.6 & 49 \\
\hline & Mean & 0.71 & 1.14 & 1.43 & 1.9 & 3.07 & 2.36 & & & & & \\
\hline $68948 B$ & 440-3-1, Bottom Ext. & 0.94 & 1 & 1 & 3 & 3 & 2 & 2 & & 23565 & 99.7 & 96 \\
\hline $68948 \mathrm{~A}$ & 4-5, Bottom Ext. & 0.84 & 1 & 1 & 3 & 3 & 2 & 2- & & 21291 & 99.6 & 96 \\
\hline \multirow[t]{2}{*}{68949} & 5-1, Bottom Ext. & 0.98 & 1 & 1 & 3 & 3 & 2 & 2 & + & 2949 & 99.94 & 85 \\
\hline & Mean & 0.92 & 1 & 1 & 3 & 3 & 2 & & & & & \\
\hline
\end{tabular}

aGas in air and cuttings; other samples are gas in air only.

TABLE 2

Results of Analyses of Extractable Bitumen $\left(\mathrm{C}_{15}{ }^{+}\right)$

\begin{tabular}{|c|c|c|c|c|c|c|c|c|c|c|}
\hline $\begin{array}{l}\text { EPR } \\
\text { No. }\end{array}$ & $\begin{array}{c}\text { Sample } \\
\text { (interval in } \mathrm{cm} \text { ) }\end{array}$ & $\begin{array}{l}\mathrm{SOM}^{\mathrm{a}} \\
(\mathrm{ppm})\end{array}$ & $\begin{array}{l}\mathrm{HCb} \\
(\mathrm{ppm})\end{array}$ & $\begin{array}{c}\mathrm{HC} / \mathrm{TOC}^{\mathrm{C}} \\
(\%)\end{array}$ & $\mathrm{HC} / \mathrm{SOM}$ & SATd $^{d}$ & $\mathrm{ARO}^{\mathrm{e}}$ & NSO $^{f}$ & ASPg & CPIh \\
\hline 68951B & $434 \mathrm{~B}-8-2,142-150$ & 407 & 106 & 1.26 & 0.26 & 12.6 & 13.4 & 53.8 & 20.3 & 3.2 \\
\hline $68955 \mathrm{~A}$ & $435 \mathrm{~A}-4-1,145-150$ & 494 & 125 & 1.16 & 0.25 & 10.6 & 14.8 & 50.9 & 23.7 & 2.8 \\
\hline $68946 \mathrm{~A}$ & 438A-5-4, Bottom Ext. & 74 & 26 & 0.7 & 0.35 & 22.3 & 13.0 & 9.3 & 55.4 & 2.1 \\
\hline 68946B & 438A-10-2, Top Ext. & 322 & 48 & 0.47 & 0.15 & 8.0 & 6.8 & 51.7 & 33.6 & 2.4 \\
\hline $68947 \mathrm{~A}$ & 438A-16-5, Top Ext. & 272 & 51 & 0.61 & 0.19 & 9.0 & 9.8 & 40.0 & 41.2 & 3.2 \\
\hline 68947B & 438A-20-1, Bottom Ext. & 236 & 62 & 0.78 & 0.26 & 15.5 & 10.7 & 41.0 & 32.7 & 3.4 \\
\hline 68948B & 440-3-1, Bottom Ext. & 343 & 75 & 1.07 & 0.22 & 4.3 & 17.6 & 53.0 & 24.9 & 3.1 \\
\hline
\end{tabular}

${ }_{\mathrm{b}}^{\mathrm{a}} \mathrm{SOM}=$ soluble organic matter (bitumen $\mathrm{C}_{15^{+}}$).

${ }^{\mathrm{b}} \mathrm{HC}=$ hydrocarbons.

${ }_{\text {TOC }}=$ total organic carbon.

$\mathrm{d}_{\mathrm{SAT}}=$ saturated hydrocarbons $\left(\%\right.$ in $\left.\mathrm{C}_{15}+\mathrm{SOM}\right)$

${ }_{\text {ARO }}=$ aromatic hydrocarbons $\left(\%\right.$ in $\left.\mathrm{C}_{15}+\mathrm{SOM}\right)$.

$\mathrm{f}_{\mathrm{NSO}}=\mathrm{N}, \mathrm{S}, \mathrm{O}$ compounds $\left(\%\right.$ in $\left.\mathrm{C}_{15^{+}} \mathrm{SOM}\right)$.

${ }_{\mathrm{h}}^{\mathrm{ASP}}=$ asphaltenes $\left(\%\right.$ in $\left.\mathrm{C}_{15}+\mathrm{SOM}\right)$.

${ }^{\mathrm{h}} \mathrm{CPI}=$ carbon preference index.

organic matter, perhaps because the sediments are redistributed from time to time by slumping.

The total-organic-carbon content of the sediments makes them adequate, but by no means excellent, potential sources of petroleum (Dow, 1977). Because their bitumen contents are roughly between 200 and 500 ppm (Table 2), we think that the sediments are poten- tially good sources for both oil and gas, given adequate burial and maturation. The quantities of bitumen in these samples overlap those in sediments from the Aleutian Trench (280-530 ppm), the southern Red Sea (113-279 ppm), and the Cariaco Trench (189-571 ppm), and can be considered typical for continental-margin environments (McIver, 1974). Ratios of hydrocarbon to 

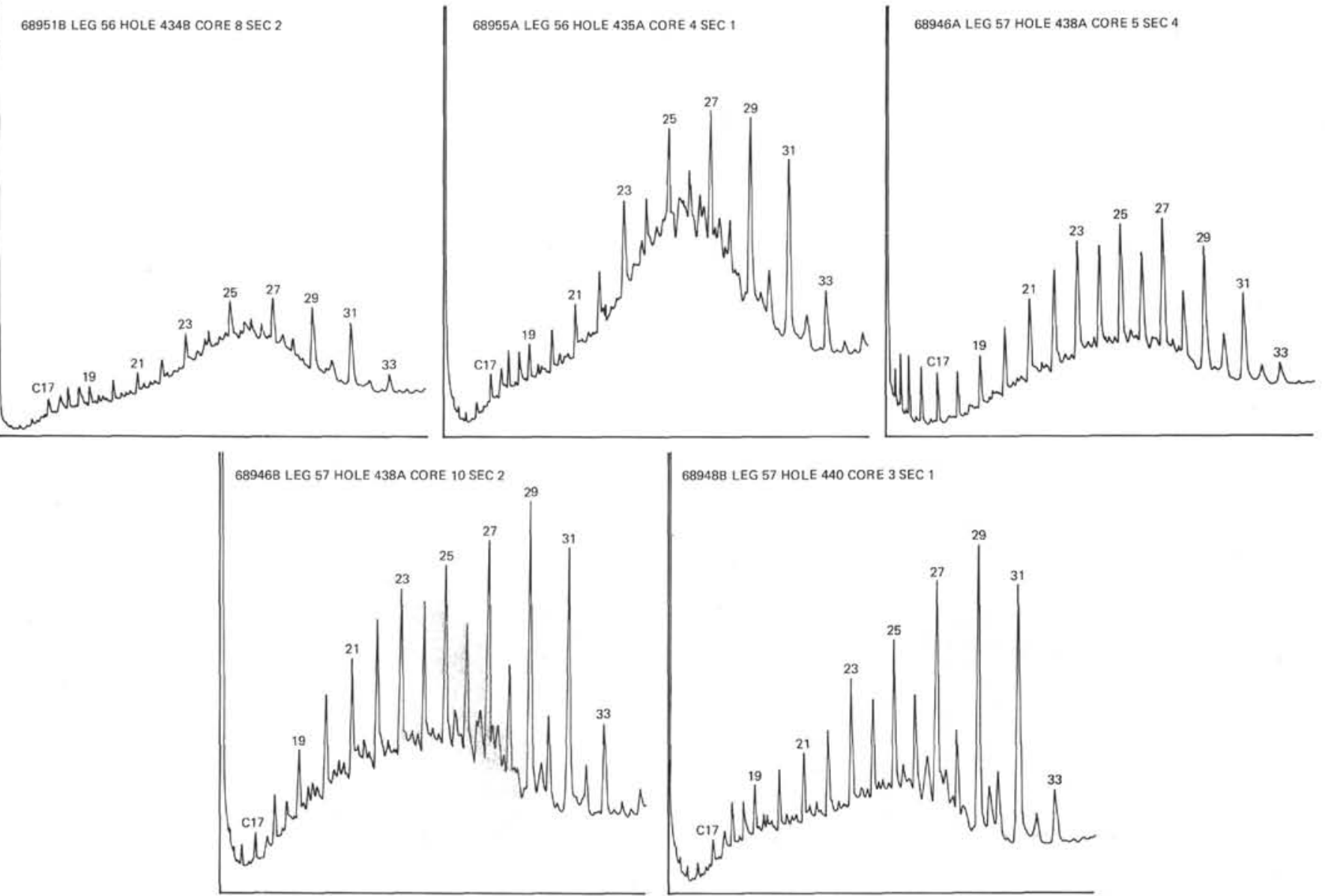

68947A LEG 57 HOLE 438A CORE 16 SEC 5

689478 LEG 57 HOLE 438A CORE 20 SEC 1
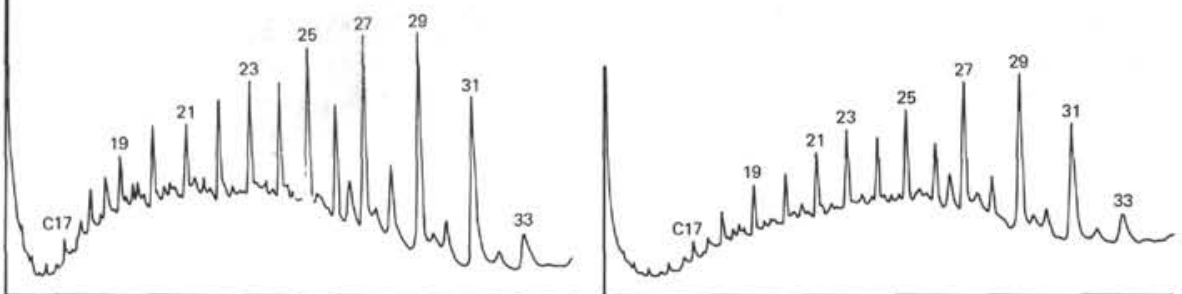

Figure 1. Gas chromatograms of the saturated $C_{15}+$ hydrocarbon fraction of selected samples.

bitumen range from 0.15 to 0.35 , again suggesting that there is a good potential for the generation of both liquid and gaseous petroleum.

At first glance, there would seem to be a conflict between the chemical data, which signal a tendency toward liquid-petroleum generation, and the kerogen data which show that gas-producing woody and coaly types of organic matter are abundant. The conflict is resolved if the amorphous material has a marine origin. This would provide each site with lipid-rich, oil-producing algal and amorphous material, as well as with terrestrial herbaceous materials that can generate both oil and gas.

The very low gas contents of some of our samples (less than $1000 \mathrm{ppm}$ ) could show that these sediments have very little potential for generating hydrocarbons (McIver, 1973c). This possibility seems unlikely, because some of the samples which are poor in gas (Table 1) are rich in extractable bitumens (Table 2). Instead, low gas contents reflect problems in sample-handling, or leakage of the storage cans (McIver, 1973a, 1973b). 
If we ignore the low-gas samples, we find that gas content increases with total organic carbon, suggesting that the gas is indigenous to the sediments (Figure 2).

\section{CONCLUSIONS}

The sediments of the landward wall of the Japan Trench contain small amounts of mostly terrestrial organic matter. They are capable, with maturation, of yielding both oil and gas. At present they are immature and contain biogenic gas. In view of the diatomaceous nature of the sediment, there is a surprising scarcity of

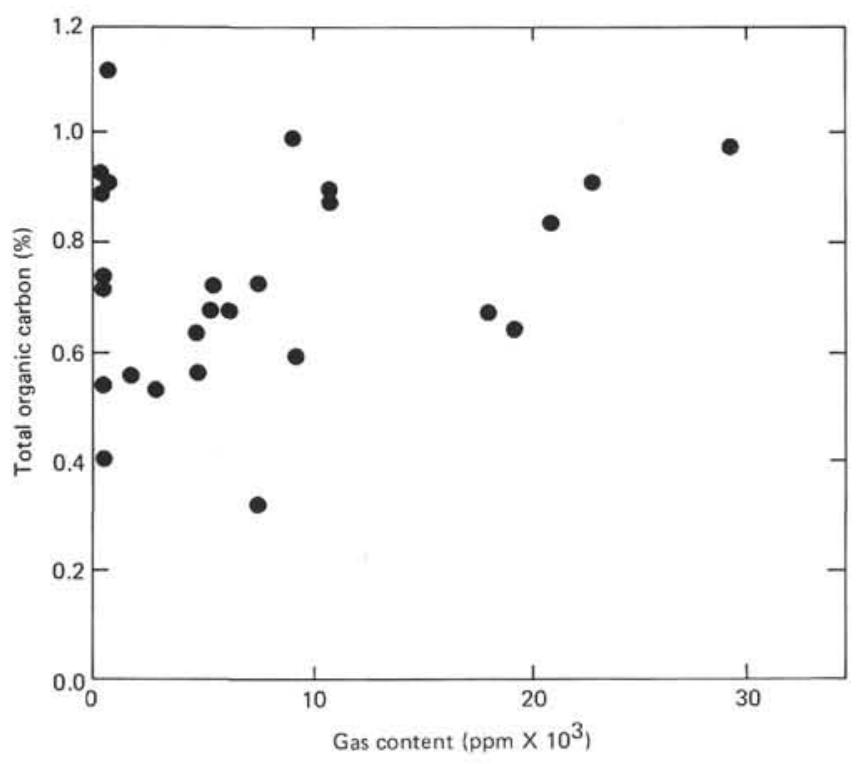

Figure 2. Gas and total-organic-carbon contents, showing tendency for gas to increase with TOC. Low gas at high total organic carbon probably due to can leakage. non-skeletal marine organic matter. We attribute this lack to rapid recycling of organic matter within the oxidizing water column.

\section{ACKNOWLEDGMENTS}

Chemical analyses were made at Exxon Production Research Company, by E. B. Brown, R. R. Barrientos, and V. M. Leopold. One of us (Gilbert) made the kerogen analyses, identified pollen, and measured thermal-alteration indexes. We thank Exxon Production Research Company for continued support of this work and for permission to publish these results. G. G. L. Rinaldi and W. A. Young reviewed this paper.

\section{REFERENCES}

Arthur, M. A., von Huene, R., Nasu, N., et al., 1978. Sedimentary history and structure of a modern empty trench. Proc. 10th Internat. Congress on Sedimentology. (Abstract)

Dow, W. G., 1977. Kerogen studies and geological interpretations. J. Geochem. Expl., 7, 79-99.

McIver, R. D., 1973a. Hydrocarbon gases from canned core samples, Sites 174A, 176, and 180. In Kulm, L. D., von Huene, R., et al., Init. Repts. DSDP, 18: Washington (U.S. Govt. Printing Office), 1013-1014.

1973b. Hydrocarbons in canned muds from Sites 185, 186, 189, and 191 -Leg 19. In Creager, J. S., Scholl, D. W., et al., Init. Repts. DSDP, 19: Washington (U.S. Govt. Printing Office), 875-877. 1973c. Low residual gas contents of four Leg 21 canned sediment samples. In Burns, R. E., Andrews, J. E., et al., Init. Repts. DSDP, 21: Washington (U.S. Govt. Printing Office), 721. 1974. Residual gas contents of organic-rich canned sediment samples from Leg 23. In Whitmarsh, R. B., Weser, O. E., Ross, D. A., et al., Init. Repts. DSDP, 23: Washington (U.S. Govt. Printing Office), 971-973.

Milliman, J. D., 1977. Effects of arid climate and upwelling upon the sedimentation regime off southern Spanish Sahara. Deep Sea Res., 24, 95-103. 